\title{
Protection against Oxygen Toxicity by Intravenous Injection of Liposome-entrapped Catalase and Superoxide Dismutase
}

Julio F. Turrens, James D. Crapo, and Bruce A. Freeman Duke University Medical Center, Durham, North Carolina 27710

bstract. Survival of rats exposed to $100 \%$ oxygen was increased from $69.5 \pm 1.5$ to $118.1 \pm 9.9 \mathrm{~h}$ (mean \pm SEM, $P<0.05$ ) when liposomes containing catalase and superoxide dismutase were injected intravenously before and during exposure. The increased survival time in $100 \%$ oxygen was also associated with significantly less fluid in the pleural cavity. Rats injected with catalaseand superoxide dismutase-containing liposomes, which had increased survival in $100 \%$ oxygen, had increased lung wet weight upon autopsy compared with saline-injected controls $(2.9 \pm 0.2 \mathrm{~g} / \mathrm{lung}$ vs. $4.8 \pm 0.4 \mathrm{~g} / \mathrm{lung}$, mean $\pm \mathrm{SE}, P<0.05)$. Intravenous injection of control liposomes along with catalase and superoxide dismutase in the suspending buffer decreased the mean pleural effusion volume $89 \%$ and had no significant effect on survival time. Lung catalase and superoxide dismutase activities were increased 3.1- and 1.7-fold, respectively, 2 $\mathrm{h}$ after a single intravenous injection of liposomes containing catalase or superoxide dismutase. Superoxide dismutase activity was also significantly greater than controls in both air- and $100 \%$ oxygen-exposed rat lungs, when enzyme activity was assayed $24 \mathrm{~h}$ after cessation of injection of control and oxygen-exposed rats with enzymecontaining liposomes every $12 \mathrm{~h}$ for $36 \mathrm{~h}$. Free superoxide dismutase and catalase injected intravenously in the absence of liposomes did not increase corresponding lung enzyme activities, affect pleural effusion volume, lung wet weight, or extend the mean survival time of rats

Preliminary results of these studies were presented at the Third International Conference on superoxide and superoxide dismutases, Ellenville, NY, October 1982.

Address all correspondence to Dr. Bruce A. Freeman.

Received for publication 24 January 1983 and in revised form 1 September 1983.

J. Clin. Invest.

(c) The American Society for Clinical Investigation, Inc.

0021-9738/84/01/0087/09 \$1.00

Volume 73, January 1984, 87-95 exposed to $100 \%$ oxygen. The clearance of liposome-augmented ${ }^{125} \mathrm{I}$-labeled catalase from lung and plasma obeyed first order kinetics according to a one-compartment model. When clearance of liposome-augmented catalase activity or radioactivity were the parameters used for pharmacokinetic studies, the half-life of augmented lung catalase was 1.9 and $2.6 \mathrm{~h}$, respectively. The half-life of liposome-entrapped catalase and superoxide dismutase activity in the circulation was 2.5 and $4 \mathrm{~h}$, respectively, while intravenously injected catalase and superoxide dismutase had a circulation half-life of 23 and $6 \mathrm{~min}$, respectively.

\section{Introduction}

A number of pharmacologic approaches have been used in attempts to prevent the toxic effect of oxygen upon lungs and most have failed to have substantial impact. Intravenous or intraperitoneal injection of corticosteroids, prostaglandin synthesis inhibitors, vitamin $\mathrm{E}$, or free superoxide dismutase (SOD) ${ }^{1}$ have not prolonged the lethal effects of $100 \%$ oxygen $(1,2)$.

Tolerance to $100 \%$ oxygen can be induced by preexposure of rats to $85 \%$ oxygen, but this tolerance-inducing exposure to hyperoxia does not prevent most of the cellular damage induced by oxygen $(3,4)$. Increased lung antioxidant enzyme activities after $85 \%$ oxygen exposure, including SOD and catalase, are an adaptive metabolic response associated with increased tissue production of oxygen metabolites and tolerance of rats to the lethal effect of $100 \%$ oxygen (3). Small doses of endotoxin also protect rats from oxygen toxicity, possibly by increasing the activity of oxygen protective enzymes including catalase, SOD, and glutathione peroxidase (5). Increased rates of superoxide and hydrogen peroxide production occur in lung tissue and in isolated lung subcellular organelles during hyperoxia (6-9). These observations support the hypothesis that an increased rate of generation of partially reduced oxygen species by lung cells is a primary mechanism of hyperoxic lung damage (10). Thus, it

1. Abbreviations used in this paper: DPPC, L- $\alpha$-dipalmitoylphosphatidylcholine; $\mathrm{LT}_{50}$, time for $50 \%$ survival; $\mathrm{SOD}, \mathrm{CuZn}$ superoxide dismutase. 
should be possible to reduce pulmonary oxygen toxicity by increasing the concentration of lung cell enzymatic defenses against generation of partially reduced species of oxygen, which include superoxide, hydrogen peroxide, and hydroxyl radical. Specific augmentation of lung catalase and SOD could both reduce oxygen toxicity and directly demonstrate the participation of reduced species of oxygen in oxygen toxicity.

Entrapment of biologically active substances in liposomes is an efficient method for delivery of macromolecules to isolated cells in vitro or target organs in vivo (11-13). Nucleic acids (14, 15 ), proteins (16), and antitumor drugs (17) can become cellassociated and biologically active, both in vitro and in vivo, using liposomes as transmembrane vectors. The intracellular content of these macromolecules can be increased severalfold.

\section{Methods}

Liposome preparation. Liposomes were prepared by reverse-phase evaporation (18) and consisted of $L-\alpha$-dipalmitoylphosphatidylcholine (DPPC)/cholesterol/stearylamine, (14:7:4, $\mathrm{mol} / \mathrm{mol})$. Lipids dissolved in chloroform (usually $25 \mathrm{ml}, 6.8 \mu \mathrm{mol} \mathrm{DPPC} / \mathrm{ml}$ ) were mixed with an aqueous solution of enzyme $(8 \mathrm{ml})$ in $4 \mathrm{mM}$ potassium phosphate, $\mathrm{pH}$ 7.4, and sonicated with a Branson sonifier, model W 185 (Heat SystemsUltrasonics, Inc., Plainview, NY) until a homogeneous emulsion was formed. Chloroform was then removed in vacuo by rotary evaporation at $43^{\circ}-46^{\circ} \mathrm{C}$

Bovine liver catalase $\left(6.5 \times 10^{4} \mathrm{U} / \mathrm{mg}\right.$ protein, Millipore/Continental Water Systems, Bedford, MA) and bovine blood CuZn SOD $\left(3.5 \times 10^{3}\right.$ U/mg protein, Diagnostic Data, Inc., Mountain View, CA) were dissolved in $4 \mathrm{mM}$ phosphate buffer, $\mathrm{pH}$ 7.4. Aqueous solutions of these enzymes were found from preliminary experiments to be stable to emulsification with chloroform and heat exposure $\left(46^{\circ} \mathrm{C}\right.$ maximum) during rotary evaporation, and suffered no losses in specific activity. Liposome concentrations are expressed per micromole phospholipid, with $100 \mu \mathrm{mol}$ phospholipid corresponding to $105 \mathrm{mg}$ total liposome lipid. Purity of DPPC (Avanti Polar Lipids, Inc., Birmingham, AL) was $>99 \%$, by thinlayer chromatography on silica gel G (Supelco, Inc., Bellefonte, PA), using chloroform/methanol/acetic acid/water, 170:25:25:6 (vol/vol) as eluent and detection of lipid phosphorus with ammonium molybdate (19).

Approximately $30 \%$ of enzyme in aqueous solution was liposome associated after reverse-phase evaporation, centrifugation, and washing, with a day-to-day variation in entrapment efficiency of $\sim 10 \%$. Enzyme to phospholipid ratios before reverse-phase evaporation were $1.6 \times 10^{4}$ $\mathrm{U}$ catalase $/ \mu \mathrm{mol}$ phospholipid and $2.0 \times 10^{2} \mathrm{U} \mathrm{SOD} / \mu \mathrm{mol}$ phospholipid. Liposomes were prepared the day before injection and assayed for enzyme content. Following reverse-phase evaporation, liposomes were separated from nonentrapped protein by centrifugation at $105,000 \mathrm{~g}$ for $40 \mathrm{~min}$ and resuspended in $0.15 \mathrm{M} \mathrm{NaCl}, 10 \mathrm{mM}$ potassium phosphate, $\mathrm{pH}$ 7.4 , yielding a liposome phospholipid concentration of $\sim 40 \mu \mathrm{mol} / 2.0$ $\mathrm{ml}$ buffer.

Control or "empty" liposomes, contained catalase and SOD in the external aqueous milieu. Control liposomes were prepared by reversephase evaporation in the presence of $4 \mathrm{mM}$ potassium phosphate, $\mathrm{pH}$ 7.4. After centrifugation, liposomes were resuspended in $0.15 \mathrm{M} \mathrm{NaCl}$,

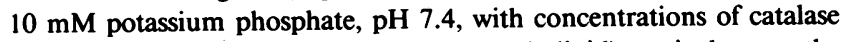
and SOD (per micromole liposome phospholipid) equivalent to the content of enzyme-containing liposomes.
Treatment of rats with liposomes and oxygen exposure. Studies were carried out using 325-350 g male, specific pathogen-free, Sprague Dawley, CD strain rats (Charles River Breeding Laboratories, Wilmington, MA). Each rat was injected with $\sim 40 \mu \mathrm{mol}$ phospholipid in $2.0 \mathrm{ml} 0.15 \mathrm{M} \mathrm{NaCl}, 10 \mathrm{mM}$ potassium phosphate, $\mathrm{pH}$ 7.4. Liposomeassociated enzyme activities are specified in Results for individual experiments. Before injection, liposomes were passed through a 27-gauge needle to disperse aggregates. All rat groups were injected in the tail vein $1 \mathrm{~h}$ before the first liposome injection with $2 \mathrm{ml} 0.2 \%$ (wt/vol) latex beads $(0.7 \mu \mathrm{m}$, Duke Scientific Corp., Palo Alto, CA) suspended in $0.15 \mathrm{M} \mathrm{NaCl}, 10 \mathrm{mM}$ potassium phosphate, $\mathrm{pH} 7.4$ (20). When studying the kinetics of liposome clearance by lungs, animals were killed for analysis at intervals after intravenous liposome injection. For oxygen toxicity studies, rats were first injected in the tail vein with $2 \mathrm{ml} 0.2 \%$ (wt/vol) latex beads and injected $1 \mathrm{~h}$ later with saline, liposome preparations, or free enzymes. Rats were then immediately exposed to $100 \%$ oxygen as previously described (4). Liposome, but not latex bead injections were repeated every $12 \mathrm{~h}$ thereafter for the first $36 \mathrm{~h}$ of oxygen exposure. Rats were maintained continuously in $100 \%$ oxygen, even when removed from exposure chambers for injection.

Biochemical analysis. Lungs were perfused through the pulmonary artery with $0.15 \mathrm{M} \mathrm{NaCl}, 10 \mathrm{mM}$ potassium phosphate, $\mathrm{pH} 7.4$, to remove blood elements for measurement of lung SOD and catalase activity and liposome uptake. Lungs were homogenized with a Polytron cell disruptor (Brinkmann Instruments, Rexdale, Ontario, Canada) in $10 \mathrm{ml} 5 \mathrm{mM}$ Tris- $\mathrm{HCl}, \mathrm{pH}$ 7.4. Lung homogenates were centrifuged at $1,400 \mathrm{~g}$ for $10 \mathrm{~min}$ to remove fibrous material that caused light scattering during spectrophotometric enzyme assays.

Control rat lungs had no $1,400-g$-sedimentable SOD and catalase activity, but perfused and liposome-treated rats had both significant sedimentable enzyme activity and ${ }^{125}$ I-labeled SOD and catalase (which for these experiments served as tracers of liposome contents) that sedimented. For the first 1-4 h after liposome injection, up to $80 \%$ of the liposome-delivered enzyme radioactivity was associated with the 1,400 $g$ pellet, suggesting sedimentation of intact liposomes with lung homogenate debris. To more accurately quantify uptake of liposomes by lungs, different methods of lung homogenization were tested to obtain optimal solubilization of the presumably intact lung-associated liposomes soon after injection. Lungs were homogenized in $5 \mathrm{mM}$ Tris- $\mathrm{HCl}$, $\mathrm{pH}$ 7.4 , containing up to $1 \%$ Triton $\mathrm{X}-100,1 \%$ sodium deoxycholate, $0.2 \%$ digitonin, or $0.2 \%$ sodium dodecyl sulfate (SDS). Greater detergent concentrations could not be tested since gel formation during homogenization made further analysis of enzymatic activity impossible. Enzyme released after homogenization in the presence of these detergents was measured by comparing the ${ }^{125}$ I-enzyme present in lung supernatants following centrifugation at $1,400 \mathrm{~g}$ with the ${ }^{125}$ I-enzyme present in aliquots of uncentrifuged homogenates of the same sample. Homogenization of lungs in the presence of $0.2 \%$ SDS gave more than a $60 \%$ solubilization of lung-associated catalase or SOD. Homogenization after the addition of the other detergents only released between 20 and $40 \%$ of the lungassociated radioactivity and, at higher concentrations, these other detergents inhibited enzyme activity. Thus, for measurement of lung SOD and catalase activities both before and after liposome treatment, all lungs were homogenized in $5 \mathrm{mM}$ Tris- $\mathrm{HCl}, 0.2 \% \mathrm{SDS}, \mathrm{pH}$ 7.4. The enzyme activity measured following homogenization with $0.2 \%$ SDS represented the total amount of enzyme delivered to the lung by liposomes. This probably underestimates the actual amount of liposome-mediated delivery of catalase and SOD to lungs by up to $40 \%$, soon after liposome injection. 
The contribution of blood cell SOD and catalase activity to perfused whole lung enzyme activity was $<5 \%$. Lung enzyme activity after oxygen exposure was affected to a greater extent by that due to residual blood content. Thus, lung enzyme activity measured after liposome injection and hyperoxic exposure was corrected for SOD and catalase content of contaminating blood. This was done using the method of Cross et al. (21). Briefly, a blood sample was removed from the inferior vena cava of rats after pentobarbital anesthesia using a heparinized syringe. The hemoglobin content of the blood sample and lung homogenate was determined, enzyme activities of blood and lung assayed, and each lung enzyme activity corrected for blood contamination, which ranged from 0 to $5 \mu \mathrm{l}$ for control rats and 12 to $60 \mu \mathrm{l}$ for rats exposed to $100 \%$ oxygen for $60 \mathrm{~h}$. Correction for blood contribution to lung enzyme activity also eliminated the artifactual increase of lung tissue SOD and catalase activity that occurred in liposome-injected rats having circulating liposome-associated enzyme activity in conjunction with blood element enzymes.

Catalase activity was assayed according to Bergmeyer (22). Whole lung SOD activity was measured according to Sjöstrom and Crapo (23) using cytochrome $c$ in the presence of $10 \mu \mathrm{M} \mathrm{KCN}$, to avoid cytochrome $c$ reoxidation by lung homogenate cytochrome $c$ oxidase. Protein was measured using the method of Lowry et al. (24) with bovine serum albumin (fraction V, Sigma Chemical Co., St. Louis, MO) as standard.

Catalase and SOD were labeled with ${ }^{125}$ I (New England Nuclear, Boston, MA) according to Hunter and Greenwood (25). Catalase and SOD lost no activity during iodination. Catalase-specific activity was $270 \mu \mathrm{Ci} / \mathrm{mg}$ protein and SOD-specific activity was $195 \mu \mathrm{Ci} / \mathrm{mg}$ protein. The rate constant for clearance of catalase activity was calculated using conventional methods based on linear regression analysis of concentration vs. time data (26).

Statistical analysis. For Table III, all data was evaluated by a oneway analysis of variance followed by Duncan's multiple-range test (27) with significance defined as $P<0.05$.

\section{Results}

Liposome entrapment of catalase and SOD and delivery to lungs. A typical preparation of liposomes containing catalase (catalase liposomes) consisted of $3,000 \mathrm{U}$ catalase $/ \mu \mathrm{mol} \mathrm{DPPC}$ while SOD-containing liposomes (SOD liposomes) consisted of 100 $\mathrm{U}$ SOD $/ \mu \mathrm{mol}$ DPPC. The apparent catalase activity of liposomes containing catalase was increased sixfold, after addition of $1 \%$ Triton X-100 and sonication (Fig. 1). An increase from virtually no detectable SOD activity to $100 \mathrm{U} \mathrm{SOD} / \mu \mathrm{mol} \mathrm{DPPC}$ was

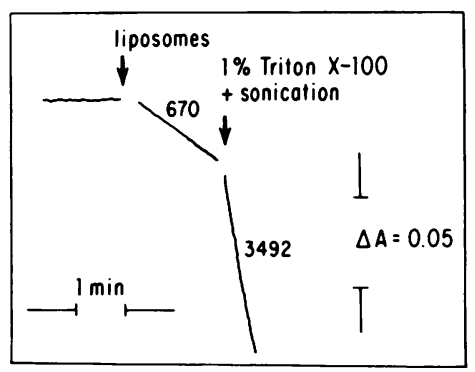

Figure 1. Effect of Triton$\mathrm{X}-100$ and sonication on the rate of $\mathrm{H}_{2} \mathrm{O}_{2}$ consumption by catalasecontaining liposomes. Liposomes $(3.2 \mathrm{nmol}$ $\mathrm{DPPC} / \mathrm{ml}$ ) were suspended in $0.15 \mathrm{M} \mathrm{NaCl}, 20 \mathrm{mM}$ potassium phosphate $(\mathrm{pH}$ 7.4). The numbers beside the trace are catalase activity in units per micromole of DPPC. also observed after liposomes containing SOD were treated with $1 \%$ Triton X-100 and sonicated. This showed that for SOD liposomes, the enzyme was predominantly liposome-entrapped. The partial catalase activity measured in intact catalase liposomes suggested either enzyme adsorption to the outer surface of liposomes or permeability of liposomes to hydrogen peroxide. Triton X-100 did not affect the activity of native catalase or SOD.

Liposome-mediated augmentation of rat lung catalase or SOD was measured $2 \mathrm{~h}$ after injection of rats with liposomes containing either catalase $\left(1.3 \times 10^{5} \mathrm{U} / \mathrm{rat}\right)$ or SOD $\left(4 \times 10^{3}\right.$ $\mathrm{U} / \mathrm{rat})$ and ${ }^{125} \mathrm{I}$-catalase $(0.5 \mu \mathrm{Ci} / \mathrm{rat})$ or $\mathrm{SOD}(0.5 \mu \mathrm{Ci} / \mathrm{rat})$. Injection of SOD and catalase liposomes increased assayable lung catalase or SOD activity 3.1- and 1.7-fold, respectively (Table I), after lungs were homogenized in the presence of $0.2 \%$ SDS. From this, it was calculated that $6.2 \%$ of injected catalase and $5.8 \%$ of injected SOD was lung associated $2 \mathrm{~h}$ after liposome injection. Intravenous injection of similar activities of free SOD or catalase did not increase lung-associated catalase or SOD activity.

Half-life of catalase in circulation and in lung. Rats were injected with $\sim 1 \mathrm{mg}$ free or liposome-entrapped SOD (Fig. 2) and catalase (Fig. 3), to determine the half-life of these enzymes in the circulation. As a control, paired rats were also injected with saline-containing ("empty") liposomes plus free enzyme. Fig. 2 shows that the circulating half-life of SOD was $8 \mathrm{~min}$ and became $4.2 \mathrm{~h}$ when liposome-entrapped. The half-life of free catalase in the circulation was $20 \mathrm{~min}$ and was $2.4 \mathrm{~h}$ when liposome entrapped (Fig. 3). The presence of "empty" liposomes (40 $\mu \mathrm{mol}$ phospholipid/rat) did not affect the circulating halflife of either free SOD or catalase (Figs. 2 and 3).

Calculations from the experiment reported in Table I and knowledge of enzyme-specific activities (Methods) showed that liposomes containing either catalase or SOD delivered similar quantities of enzyme protein to lungs (75-125 $\mu \mathrm{g}$ protein).

Table I. Lung SOD and Catalase Activity 2 h After Intravenous Injection of Liposomes-entrapped SOD and Catalase

\begin{tabular}{lll}
\hline Treatment & SOD & Catalase \\
\hline & U/lung & U/lung \\
Control & $317 \pm 47$ & $3,588 \pm 201$ \\
CuZn SOD liposomes & $548 \pm 51^{*}$ & - \\
Catalase liposomes & - & $11,147 \pm 254^{*}$
\end{tabular}

Rats were injected with $2 \mathrm{ml}$ liposomes consisting of $1.2 \times 10^{5} \mathrm{U}$ catalase or $4 \times 10^{3} \mathrm{U}$ SOD entrapped in $\sim 35 \mu \mathrm{mol}$ liposome phospholipid. 2 $h$ later, the animals were killed and lungs perfused with saline through the pulmonary artery. Lungs were homogenized in $5 \mathrm{mM}$ potassium phosphate buffer, $0.2 \% \mathrm{SDS}, \mathrm{pH} 7.4$. Values represent the mean $\pm \mathrm{SE}$ of the enzyme activity of five rat lungs.

* $P<0.05$, significantly different from controls using Duncan's multiple range test. 


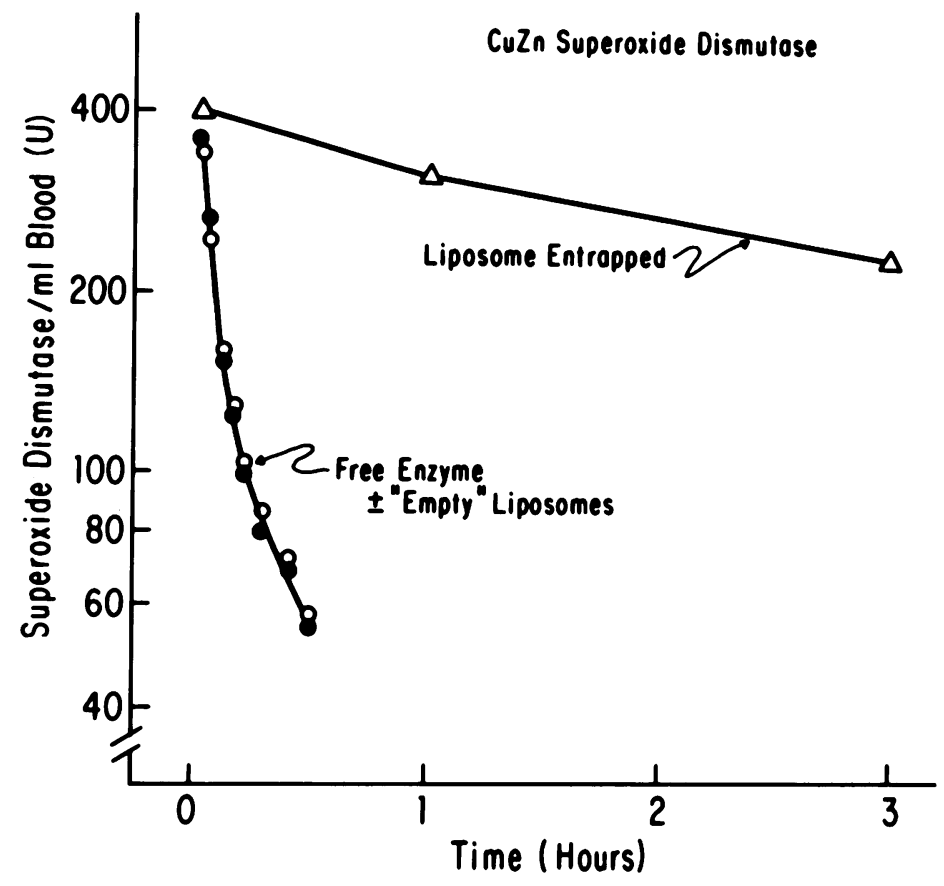

Figure 2. Clearance of free and liposome-entrapped CuZn SOD from the rat circulation. Rats were injected in the tail vein with enzyme and/or liposomes having a total volume of $1.0 \mathrm{ml}$, in $0.15 \mathrm{M} \mathrm{NaCl}, 10 \mathrm{mM}$ potassium phosphate, $\mathrm{pH}$ 7.4. Injections consisted of 4,000 U CuZn SOD (๑), 4,000 U CuZn SOD plus "empty" liposomes containing $40 \mu \mathrm{mol}$ phospholipid $(O)$, or 4,000 U CuZn SOD entrapped in liposomes containing 40 $\mu$ mol phospholipid $(\Delta)$. At selected intervals, 100- $\mu$ l blood samples for enzyme assay were removed from the inferior vena cava of pentobarbital-anesthetized rats, centrifuged, hematocrit determined, and enzyme activity of the serum determined. Activity per milliliter whole blood was then calculated from the packed cell volume of each sample.
However, the combination of endogenous lung catalase and SOD activities and the greater specific activity of catalase (6-7 $\times 10^{4} \mathrm{U} / \mathrm{mg}$ protein $)$ compared with SOD $\left(3 \times 10^{3} \mathrm{U} / \mathrm{mg}\right.$ protein) resulted in a greater degree of liposome-dependent augmentation of endogenous lung catalase activity than SOD activity (Table I). Because a greater increase in catalase activity compared with controls was obtained following liposome injection, catalase was chosen for measurement of liposome-augmented enzyme half-life in lung. SOD delivered via liposomes may have a different half-life in lungs.

Rats were given a single injection of liposomes containing $4.5 \times 10^{4} \mathrm{U}$ catalase and $0.2 \mu \mathrm{Ci}{ }^{125} \mathrm{I}$-catalase for studying the clearance of liposome-entrapped enzyme from lungs. A 4.3-fold increase in rat lung catalase activity was measured $15 \mathrm{~min}$ after

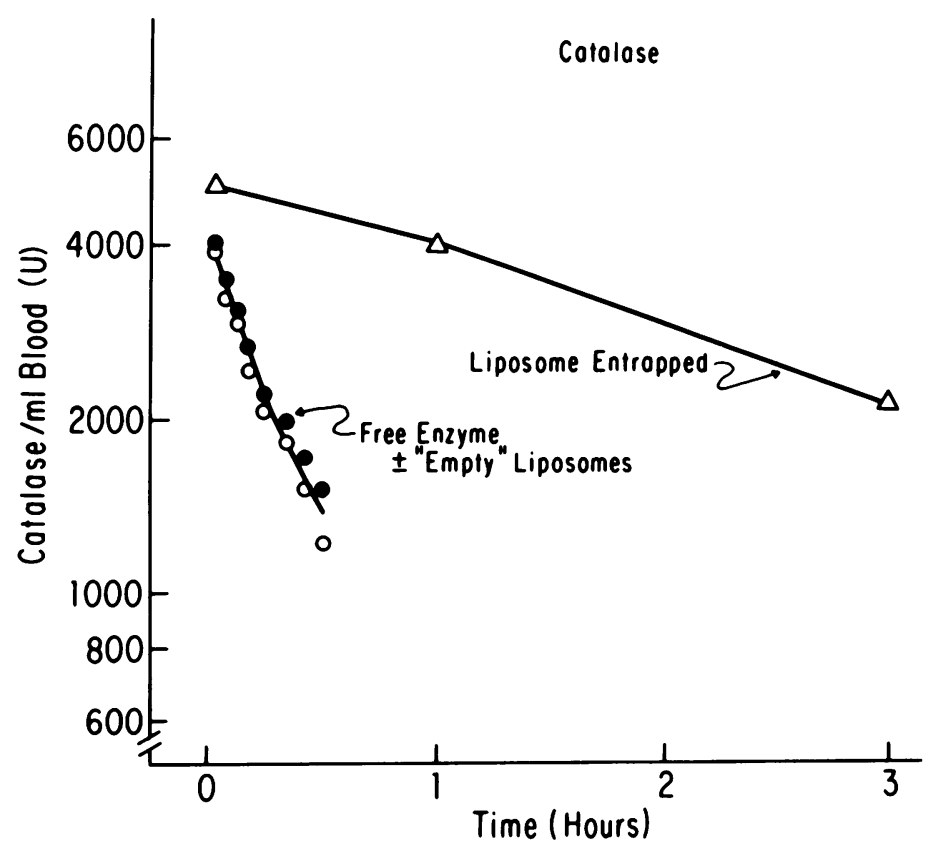

Figure 3. Clearance of free and liposome-entrapped catalase from the rat circulation. This experiment was performed as in Fig. 2, except rats were each injected with $60,000 \mathrm{U}$ catalase. $(\bullet)$ represents rats injected with free catalase; $(O)$ represents free catalase plus "empty" liposomes; and $(\mathbf{\Lambda})$ represents rats injected with $60,000 \mathrm{U}$ catalase entrapped in liposomes containing $40 \mu \mathrm{mol}$ phospholipid. 
catalase liposome injection (Fig. 4). ${ }^{125}$ I-Catalase delivered via liposomes was cleared from lung and obeyed first order kinetics for $6 \mathrm{~h}$ after injection. $24 \mathrm{~h}$ after injection of liposomes, $1,800 \pm 200 \mathrm{cpm}$ remained in lung tissue. At this time, catalase activity in lungs was not significantly different from controls, suggesting that the ${ }^{125}$ I was not associated with active enzyme. Catalase activity decreased in rat lungs according to first order kinetics for up to $12 \mathrm{~h}$ after liposome injection. The half-lives of liposome-augmented lung catalase activity calculated from enzyme activity and radiolabel methods were 1.9 and $2.6 \mathrm{~h}$, respectively (Fig. 4). The first order rate constants for the decrease in catalase activity and radiolabel were 0.37 and $0.25 \mathrm{~h}^{-1}$, respectively. The decrease in liposome-augmented blood catalase activity also occurred according to first order kinetics and had a half-life of $2.4 \mathrm{~h}$ and a first order rate constant of $0.37 \mathrm{~h}^{-1}$ (Fig. 3).

When the ${ }^{125}$ I-catalase content per lung was calculated from data obtained at $\mathrm{t}=15 \mathrm{~min}$ in Fig. 2 and compared with the amount of ${ }^{125}$ I-catalase injected with liposomes, it was calculated that $13.3 \%$ of injected catalase was associated with lung tissue at this time point. These observations confirm the findings of other investigators that circulating liposome uptake by lungs is rapid and extensive (28).

Liposome-mediated augmentation of lung SOD and catalase activity was also studied by assaying control and $100 \%$ oxygenexposed lung enzyme activities $24 \mathrm{~h}$ after cessation of liposome injections (Table II). Rats were injected intravenously with 1 $\times 10^{5} \mathrm{U}$ catalase and $6 \times 10^{3} \mathrm{U}$ SOD in $35 \mu \mathrm{mol}$ liposome phospholipid, immediately before air or $100 \%$ oxygen exposure

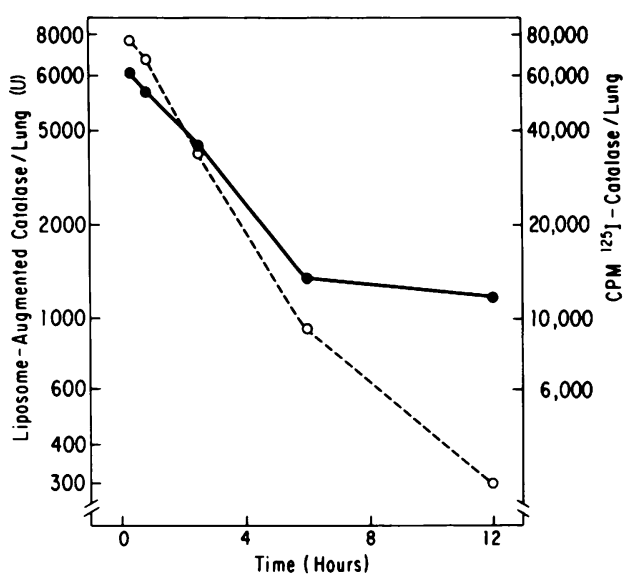

Figure 4. Clearance of liposome-delivered catalase activity and ${ }^{125} \mathrm{I}-$ catalase from lung. Animals were injected with liposomes containing catalase and killed at different periods of time. The amount of delivered catalase was calculated as the difference between catalase content in treated animals and catalase content in control animals at different times after injection of liposomes. Lungs were perfused and homogenized before determination of catalase activity $(\mathrm{O})$ and radioactivity $(\bullet)$
Table II. Effect of 100\% Oxygen Exposure on Lung SOD and Catalase Activity After Intravenous Injection of Liposomeentrapped SOD and Catalase

\begin{tabular}{lll}
\hline Treatment & SOD & Catalase \\
\hline & U/lung & U/lung \\
Air-exposed rats & $335 \pm 26^{*}$ & $3,449 \pm 145^{*}$ \\
$\begin{array}{l}\text { Air-exposed rats injected with SOD } \\
\text { plus catalase-containing }\end{array}$ & & \\
$\quad$ liposomes & $624 \pm 35 \ddagger$ & $3,570 \pm 201^{*}$ \\
$\begin{array}{l}\text { 100\% oxygen, 60-h-exposed rats } \\
\text { 100\% oxygen, 60-h-exposed rats } \\
\text { injected with SOD plus catalase- } \\
\text { containing liposomes }\end{array}$ & $329 \pm 22^{*}$ & $3,520 \pm 185^{*}$ \\
\hline & $544 \pm 21 \ddagger$ & $3,893 \pm 177^{*}$ \\
\hline
\end{tabular}

Rats were injected four times with either $2 \mathrm{ml}$ saline or $2 \mathrm{ml}$ liposomes every $12 \mathrm{~h}$ for $36 \mathrm{~h}$. Oxygen-treated rats were injected immediately before beginning $100 \%$ oxygen exposure. Lung enzyme activity was assayed $60 \mathrm{~h}$ after the initial injection of animals ( $24 \mathrm{~h}$ after final injection). * $\ddagger$ Values having the same symbol superscript are not significantly different from each other, using Duncan's multiple range test that compares intergroup differences $(P<0.05, n=5)$. Each treated rat received intravenous injection of $2 \mathrm{ml}$ liposomes consisting of $1.0 \times 10^{5} \mathrm{U}$ catalase and $6 \times 10^{3} \mathrm{U}$ SOD in $\sim 60 \mu \mathrm{mol}$ liposome phospholipid and was corrected for enzyme activity contamination due to blood elements.

$(\mathrm{t}=0)$ and at $\mathrm{t}=12,24$, and $36 \mathrm{~h}$. This is the same injection schedule used for oxygen toxicity studies reported in Table III and Fig. 5. Table II shows that only SOD was significantly increased (186\%) $24 \mathrm{~h}$ after liposome injections were stopped, in both air- and $100 \%$ oxygen-exposed rats. There was no significant change in both SOD and catalase activity in noninjected $100 \%$ oxygen-exposed rat lungs, agreeing with previous observations (4). Liposome-injected rats exposed to $100 \%$ oxygen did not have significantly different SOD and catalase activity, compared with liposome-injected rats maintained in room air, showing that $100 \%$ oxygen did not further increase the activity of these antioxidant enzymes.

Protection of rats against oxygen toxicity. Groups of rats were exposed to $100 \%$ oxygen and injected every $12 \mathrm{~h}$, beginning at $\mathrm{t}=0$ with saline, control liposomes, free catalase and SOD, control liposomes plus free catalase and SOD, liposomes containing SOD alone, liposomes containing catalase alone or both SOD and catalase-containing liposomes. Rats were kept in $100 \%$ oxygen continuously, even when given injections after beginning $100 \%$ oxygen exposure. Lung wet weight and the amount of pleural effusion present after death were measured upon autopsy (Table III). Exposed rats injected with catalase plus SOD liposomes, catalase liposomes, and control liposomes plus free catalase and SOD had significantly less fluid in the pleural cavity after death compared with saline-injected controls $(0.5 \pm 0.3 \mathrm{ml}$, $2.1 \pm 1.0 \mathrm{ml}$, and $4.9 \pm 1.4 \mathrm{ml}$, respectively, all $P<0.05$, mean \pm SEM) (Table III). Only rats injected with catalase plus 
Table III. Survival Time, Lung Wet Weight, and Pleural Effusion Volume of Animals Exposed to $100 \%$ Oxygen

\begin{tabular}{|c|c|c|c|c|c|c|}
\hline Treatment* & $n$ & $\begin{array}{l}\text { Lung wet } \\
\text { weight }\end{array}$ & $n$ & $\begin{array}{l}\text { Pleural } \\
\text { effusion }\end{array}$ & $n$ & Survival time \\
\hline & & $g$ & & $m l$ & & $h$ \\
\hline Saline & 27 & $2.92 \pm 0.16 \ddagger$ & 24 & $9.8 \pm 0.4 \ddagger$ & 21 & $69.5 \pm 1.5 \ddagger$ \\
\hline Free catalase plus SOD & 8 & $2.66 \pm 0.09 \ddagger$ & 8 & $9.2 \pm 1.2 \ddagger$ & 11 & $71.4 \pm 1.7 \ddagger$ \\
\hline Empty liposomes & 8 & $2.98 \pm 0.18 \ddagger \S$ & 8 & $9.4 \pm 0.7 \ddagger$ & 10 & $71.2 \pm 1.5 \ddagger$ \\
\hline Catalase liposomes & 7 & $3.57 \pm 0.43 \ddagger \S$ & 6 & $4.9 \pm 1.4$ & 7 & $74.4 \pm 7.3 \ddagger$ \\
\hline SOD liposomes & 7 & $2.80 \pm 0.16 \ddagger$ & 7 & $9.0 \pm 0.5 \ddagger$ & 7 & $72.4 \pm 1.6 \ddagger$ \\
\hline $\begin{array}{l}\text { Empty liposomes with free } \\
\text { SOD, SOD plus catalase } \\
\text { Liposomes containing }\end{array}$ & 9 & $3.80 \pm 0.25 \S$ & 10 & $2.1 \pm 1.0 \S$ & 9 & $83.1 \pm 3.1 \ddagger$ \\
\hline SOD plus catalase & 11 & $4.83 \pm 0.36$ & 11 & $0.5 \pm 0.3 \S$ & 12 & $118.1 \pm 9.9$ \\
\hline
\end{tabular}

\footnotetext{
* Rats were injected intravenously with a total volume of $2 \mathrm{ml}$ saline or a suspension of liposomes (60$90 \mu \mathrm{mol}$ DPPC) containing either saline, catalase $\left(8-9.8 \times 10^{4} \mathrm{U}\right)$, or SOD $\left(2-3 \times 10^{3} \mathrm{U}\right)$ suspended in saline. Free catalase $\left(5 \times 10^{4} \mathrm{U} / \mathrm{ml}\right)$ and SOD $\left(2 \times 10^{3} \mathrm{U} / \mathrm{ml}\right)$ were injected in $2 \mathrm{ml}$ saline.

$\ddagger \S$ Values having the same symbol superscript are not significantly different from each other $(P<0.05)$. All values represent mean \pm SEM and are compiled from experiments done on three to five separate occasions.
}

SOD liposomes had significantly greater survival time in $100 \%$ oxygen. The time for $50 \%$ survival $\left(\mathrm{LT}_{50}\right)$ for this group of rats increased from $69.5 \pm 1.5$ to $118 \pm 9.9 \mathrm{~h}(P<0.05$, mean \pm SEM, Table III and Fig. 5).

\section{Discussion}

Intravenous injection of liposomes containing catalase plus SOD increased the survival time of rats exposed to $100 \%$ oxygen. The $\mathrm{LT}_{50}$ increased from 70 to $110 \mathrm{~h}$ and the volume of pleural effusion at autopsy decreased from $9.8 \pm 0.5$ to $0.4 \pm 0.3 \mathrm{ml}$ (Table
III, Fig. 5). Protection appears to be due to the antioxidant activity of both catalase and SOD, since liposomes containing either catalase or SOD alone and control liposomes plus free catalase and SOD did not increase $\mathrm{LT}_{50}$. A single injection of liposomes containing catalase and SOD increased the activity of these enzymes in rat lungs 3.1- and 1.7-fold, respectively, 2 $h$ after injection (Table I). In a separate experiment, it was shown that $24 \mathrm{~h}$ after cessation of injection of SOD plus catalase liposomes (injections given every $12 \mathrm{~h}$ for $36 \mathrm{~h}$ as for $100 \%$ oxygen exposure), lung SOD activity was significantly greater than controls, in both air and $100 \%$ oxygen-exposed groups

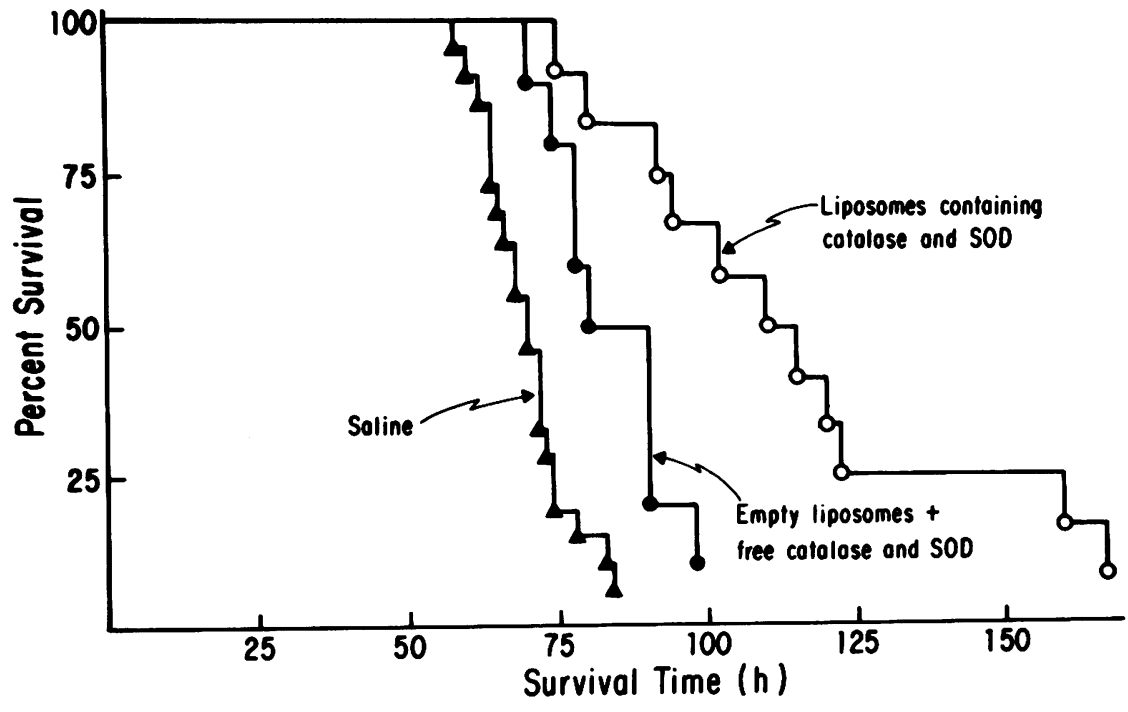

Figure 5. Effect of liposomal treatment on survival of rats in $100 \%$ oxygen. Animals were injected intravenously every $12 \mathrm{~h}$ as described in Methods with saline ( $\Delta$ ), empty liposomes (equivalent to $85 \mu \mathrm{mol}$ DPPC) plus $3 \times 10^{3} \mathrm{U}$ SOD and $9 \times 10^{4} \mathrm{U}$ catalase $(\bullet)$ or liposomes containing $\sim 3 \times 10^{3} \mathrm{U}$ SOD and $9 \times 10^{4} \mathrm{U}$ catalase $(O)$. 
(Table II). Augmentation of catalase activity was not apparent at this time point, possibly because of a faster rate of clearance or degradation of this liposome-delivered enzyme in lungs compared with SOD. Figs. 2 and 3 show that the circulating halflife of catalase liposomes is less than that of SOD liposomes.

The injection of control liposomes plus free SOD and catalase or liposomes containing catalase significantly decreased the appearance of fluid in the pleural cavity, but did not significantly increase the $\mathrm{LT}_{50}$ of rats exposed to $100 \%$ oxygen. The possible adsorption of catalase onto the surface of liposomes (Fig. 1) may result in intracellular delivery of this enzyme, when injected as the free enzyme in the presence of control liposomes, and may explain the decreased pleural effusion measured in rats injected with free enzymes plus control liposomes (Table III).

Intravenously injected liposomes will primarily interact with the first lung cell surface they come in contact with, a likely candidate being the capillary endothelial cell. Since this cell type accounts for $14 \%$ of the total cell volume of rat lungs (4), it is possible that liposome-mediated augmentation of enzyme activity occurs in this cell type, which cannot be detected by enzyme assay of whole lung homogenates at extended times after liposome injection.

The half-life of intravenously injected native SOD and catalase in the circulation was 8 and $20 \mathrm{~min}$, respectively, in agreement with previous observations (29). The shorter circulating half-life of the smaller CuZn SOD (31,000 mol wt) may be due to more rapid renal clearance, compared with catalase $(210,000$ mol wt). Liposome entrapment significantly extended the circulating half-life of these enzymes up to $5 \mathrm{~h}$, depending on the enzyme content. This half-life for circulating liposomes is similar to previous observations, for liposomes having similar composition and different contents (28). The clearance of SOD and catalase from the circulation and catalase from lungs obeyed first order kinetics, according to a one-compartment model (Figs. $2-4,[26,28])$. The rate constant of catalase radioactivity clearance from both blood and lung decreased significantly at $6 \mathrm{~h}$ after injection (Fig. 4). This change in the rate constant is probably due to loss of ${ }^{125} \mathrm{I}$-label from catalase rather than biphasic kinetics of clearance. Catalase activity assay at various times after injection supports this conclusion. The lung capillary bed is the first to come in contact with intravenously injected liposomes. $15 \mathrm{~min}$ after injection of liposomes, $14 \%$ of liposomal ${ }^{125} \mathrm{I}$-catalase was associated with the lung. After injection of 4.44 $\times 10^{5} \mathrm{cpm}$ liposome-entrapped catalase, $6,200 \pm 344 \mathrm{cpm} / \mathrm{ml}$ blood (mean $\pm \mathrm{SD}, n=4$ ) was found in the circulation $15 \mathrm{~min}$ after liposome injection. Since a $270-\mathrm{g}$ rat has $\sim 15 \mathrm{ml}$ blood (30), it was calculated that $20 \%$ of injected liposomes remained in circulation at this point, either free or blood cell-associated.

The rats injected with liposomes containing catalase and SOD had the least pleural effusion and the longest survival time in $100 \% \mathrm{O}_{2}$. Liposome-dependent protection against $100 \%$ oxygen, measured by survivorship, did not include prevention of increased lung wet weight resulting from oxygen exposure. The mechanism explaining the greater lung wet weight in these an- imals is not clear. It may be that these animals survived for longer periods of time, permitting a greater degree of interstitial and intraalveolar edema to occur in portions of the lungs. The massive pleural effusions present in several of the groups (Table III) must have significantly contributed to compromise of pulmonary gas exchange and been an important factor in their death. Prevention of these pleural effusions may have helped extend the survival time of the animals treated with liposomeentrapped enzymes, while the gradual accumulation of intrapulmonary fluid indicated another somewhat slower component of lung injury, which subsequently contributed to death. The presence of a small pleural effusion but relatively little extension of survival time in the animals treated with empty liposomes and free catalase and SOD indicated that pleural effusion is not the only factor contributing to the death of the other exposure groups.

Liposomes are a useful vector for mediating intracellular delivery of biologically active substances (11-13). Several techniques have been developed for liposome entrapment of solutes. Reverse-phase evaporation provided efficient entrapment of large amounts of solute and yields liposomes that are predominantly unilamellar and range from 0.1 to $1 \mu \mathrm{m}$ in diameter (13). Treatment with $0.2 \%$ SDS was needed to release most liposomedelivered catalase from lung homogenates, suggesting that a significant proportion of liposomes remained intact in lung cells $2 \mathrm{~h}$ after injection. Transfer of liposome contents to cytosol has been shown to occur over a period of a few hours (31). A number of approaches, such as varying liposome size by preparation methodology and altering charge, by using positive and negative amphiphiles, will alter tissue distribution of intravenously injected liposomes. In addition, mechanisms of liposome uptake by cells may be altered by changes in liposome physical characteristics (32). Contradictory liposome size and charge characteristics for optimal organ and cell uptake have been reported $(20,33-35)$.

Since liposomes were administered intravenously, both lung capillary endothelial cells and phagocytic cells (capable of ingesting liposomes and marginating into lung tissue [36-38]) are potential lung cell types that would interact with liposomes. It remains to be determined whether the liposomes became associated with lung cells by adsorption to cell surfaces, fusion with cell membranes, phagocytosis, or by a combination of these mechanisms (31). Even though intravenous injection of rats with liposomes containing SOD or catalase increased whole lung SOD and catalase activity between 1.7- and threefold (Table I), the actual concentration of these enzymes in the cellular milieu of target cells was probably severalfold greater because of preferential uptake by specific lung cell types. In vitro studies of cultured porcine aortic endothelial cells have shown that liposome-mediated SOD delivery can augment endogenous cellular enzyme activity up to sevenfold, and will also render the cells more resistant to hyperoxic injury (39).

Oxygen toxicity is due in part to increased generation of superoxide and hydrogen peroxide in lung cells $(7-10)$. The 
experiments described in this report show that augmentation of lung defenses against superoxide and hydrogen peroxide using SOD- and catalase-containing liposomes can decrease oxygen injury. The need for liposome-mediated augmentation of both enzymes, for extension of survival time, suggests that both superoxide and hydrogen peroxide are important mediators of in vivo oxygen injury. Following intravenous injection and tissue uptake, liposome-delivered catalase and SOD could scavenge either subcellular organelle-derived oxygen species or partially reduced species of oxygen generated by phagocytic cells infiltrating into or residing in oxygen-damaged lungs $(40,41)$. It may be possible to extend the use of liposomes containing antioxidant enzymes to other situations where tissue damage due to overproduction of partially reduced oxygen species is problematic, such as inflammation, toxicity from quinoid antibiotics and anthracyclic chemotherapeutic agents, paraquat poisoning (42), or ischemia reperfusion injury (43).

\section{Acknowledgments}

This work was supported by the American Lung Association, and National Institutes of Health grants HL29784 and HL-25044.

\section{References}

1. Yam, J., and R. J. Roberts. 1979. Pharmacological alterations of oxygen-induced lung toxicity. Toxicol. Appl. Pharmacol. 47:367-375.

2. Crapo, J. D., D. M. Delong, K. Sjöstrom, G. Hasler, and R. T. Drew. 1977. The failure of aerosolized superoxide dismutase to modify pulmonary oxygen toxicity. Am. Rev. Respir. Dis. 115:1027-1033.

3. Crapo, J. D., D. F. Tierney. 1974. Superoxide dismutase and pulmonary oxygen toxicity. Am. J. Physiol. 226:1401-1407.

4. Crapo, J. D., B. E. Barry, H. A. Foscue, and J. Shelburne. 1980. Structural and biochemical changes in rat lungs occurring during exposure to lethal and adaptive doses of oxygen. Am. Rev. Respir. Dis. 122:123143.

5. Frank, L., J. Yam, and R. J. Roberts. 1978. The role of endotoxin in protection of adult rats from oxygen-induced lung toxicity. J. Clin. Invest. 61:269-275.

6. Freeman, B. A., and J. D. Crapo. 1981. Hyperoxia increases oxygen radical production in rat lungs and lung mitochondria. $J$. Biol. Chem. 256:10986-10992.

7. Freeman, B. A., M. K. Topolosky, and J. D. Crapo. 1982. Hyperoxia increases oxygen radical production in rat lung homogenates. Arch. Biochem. Biophys. 216:477-484.

8. Turrens, J. F., B. A. Freeman, J. G. Levitt, and J. D. Crapo. 1982. The effect of hyperoxia on superoxide production by lung submitochondrial particles. Arch. Biochem. Biophys. 217:401-410.

9. Turrens, J. F., B. A. Freeman, and J. D. Crapo. 1982. Hyperoxia increases $\mathrm{H}_{2} \mathrm{O}_{2}$ release by lung mitochondria and microsomes. Arch. Biochem. Biophys. 217:411-421.

10. Gerschman, R. 1964. Biological effects of oxygen. In Oxygen in the Animal Organism. F. Dickens and E. Neil, editors. Macmillan, Inc., New York. 475-494.

11. Tyrrell, D. A., T. D. Heath, C. M. Colley, and B. E. Ryman. 1976. New aspects of liposomes. Biochim. Biophys. Acta. 457:259-302.

12. Juliano, R. L., and D. Layton. 1980. Liposomes as a drug delivery system. In Drug Delivery Systems: Characteristics and Biomedical Applications. R. L. Juliano, editor. Oxford Book Co., Inc., New York.

13. Szoka, F., and D. Papahadjopoulos. 1980. Comparative properties and methods of preparation of lipid vesicles. Annu. Rev. Biophys. Bioeng. 9:467-508.

14. Schaefer-Ridder, M., Y. Wang, and P. H. Hofschneider. 1982. Liposomes as gene carriers: efficient transformation of mouse $\mathbf{L}$ cells by thymidine kinase gene. Science (Wash. DC). 215:166-168.

15. Lavelle, D., W. P. Paxton, D. I. Blaustein, M. J. Ostro, and D. Giacomoni. 1982. Improved methods for the delivery of liposome-sequestered RNA into eukaryotic cells. Arch. Biochem. Biophys. 215:486497.

16. Takada, G., H. Onodera, and K. Tada. 1982. Delivery of fungal $\beta$-galactosidase to rat brain by means of liposomes. Tohoku J. Exp. Med. 136:219-229.

17. Kimelberg, H. K., T. F. Tracy, S. M. Biddlecome, and R. S. Bourke. 1976. Effect of entrapment in liposomes on the in vivo distribution of ${ }^{3} \mathrm{H}$-methotrexate in a primate. Cancer Res. 36:2949-2967.

18. Szoka, F., and D. Papahadjopoulos. 1978. Procedure for preparing liposomes with large internal aqueous space and high capture by reverse-phase evaporation. Proc. Natl. Acad. Sci. USA. 75:4194-4198.

19. Dittmer, J. D., and R. L. Lester. 1964. A simple specific spray for detection of phospholipids on thin-layer chromatograms. J. Lipid. Res. 5:126-131.

20. Kao, Y. J., and R. L. Juliano. 1981. Interactions of liposomes with the reticuloendothelial system: effects of reticuloendothelial blockade on the clearance of large unilamellar vesicles. Biochim. Biophys. Acta. 677:453-461.

21. Cross, C. E., T. T. Watanabe, G. K. Hasegawa, G. N. Goralnik, K. E. Roertgen, T. Kaizu, K. M. Reiser, A. B. Gorin, and J. A. Last. 1979. Biochemical assays in lung homogenates: artifacts caused by trapped blood after perfusion. Toxicol. Appl. Pharmacol. 48:99-107.

22. Bergmeyer, H. U. 1955. Zur messung nov Katalase-aktivatäten. Biochem. Z. 327:255-258.

23. Sjöstrom, K., and J. D. Crapo. 1983. Structural and biochemical adaptive changes in rat lungs after exposure to hyperoxia. Lab. Invest. 48:68-79.

24. Lowry, O. H., N. J. Rosebrough, A. L. Farr, and R. J. Randall. 1951. Protein measurement with the Folin phenol reagent. J. Biol. Chem. 193:265-277.

25. Hunter, W. M., and F. C. Greenwood. 1962. Labeling of proteins with ${ }^{125}$ I using chloramine T. Nature (Lond.). 194:495-496.

26. Gibaldi, M., and D. Perrier. 1975. In Pharmacokinetics. Marcel Dekker, Inc., New York. 1-43.

27. Duncan, D. B. 1955. Multiple range and multiple F tests. Biometrics. 11:1-23.

28. Juliano, R. L., and D. Stamp. 1978. Pharmacokinetics of liposome-encapsulated anti-tumor drugs. Biochem. Pharmacol. 27:2127.

29. McCord, J. M., and K. Wong. 1979. Phagocyte-produced free radicals: roles in cytotoxicity and inflammation. In Oxygen-Free Radicals and Tissue Damage. Ciba Found. Symp. 65:343-360.

30. Donaldson, H. H. 1924. Hematological aspects. In The Rat. H. H. Donaldson, editor. Memoirs of the Wistar Institute of Anatomy and Biology No. 6, Philadelphia.

31. Pagano, R. E., A. J. Schroit, and D. K. Struck. 1981. Interaction of phospholipids vesicles with mammalian cells in vitro: studies of mechanism. In Liposomes: From Physical Structure to Therapeutic Ap- 
plications. C. G. Knight, editor. Elsevier North-Holland, Inc., New York. 323-348.

32. Straubinger, R. M., K. Hong, D. Friend, and D. Papahadjopoulos. 1983. Endocytosis of liposomes and intracellular fate of encapsulated molecules: encounter with a low $\mathrm{pH}$ compartment after internalization in coated vesicles. Cell. 32:1069-1079.

33. Michelson, A. J., K. Puget, and P. Durosay. 1981. Studies of liposomal superoxide dismutase in rats. Mol. Physiol. 1:85-96.

34. Hunt, C. A., Y. M. Rustum, E. Mayhew, and D. Papahadjopoulos. 1979. Retention of cytosine arabinoside in mouse lung following intravenous administration in liposomes of different size. Drug Metab. Dispos. 7:124-128.

35. Machy, P., and L. D. Leserman. 1983. Small liposomes are better than large liposomes for specific drug delivery in vitro. Biochim. Biophys. Acta. 730:313-320.

36. Shephard, E. G., J. R. Joubert, M. C. Finkelstein, and S. H. Kuhn. 1981. Phagocytosis of liposomes by human alveolar macrophages. Life Sci. 29:2691-2698.

37. Kuhn, S. H., B. Gemperli, E. G. Shephard, J. R. Joubert, P. A. C. Weidemann, G. Weismann, and M. C. Finkelstein. 1983. In- teraction of liposomes with human leukocytes in whole blood. Biochim. Biophys. Acta. 762:119-127.

38. Poste, G., C. Bucana, A. Raz, P. Bugelski, R. Kirsh, and I. J. Fidler. 1982. Analysis of the fate of systemically administered liposomes and implications for their use in drug delivery. Cancer Res. 42:14121422 .

39. Freeman, B. A., J. D. Crapo, and S. L. Young. 1983. Liposomemediated augmentation of superoxide dismutase in endothelial cells prevents oxygen injury. J. Biol. Chem. 258:12534-12542.

40. Fox, R. B., J. R. Hoidal, D. M. Brown, and J. E. Repine. 1981. Pulmonary inflammation due to oxygen toxicity: involvement of chemotactic factors and polymorphonuclear leukocytes. Annu. Rev. Respir. Dis. 123:521-523.

41. Freeman, B. A., B. E. Barry, and J. D. Crapo. 1982. The contribution of inflammatory cells to lung superoxide production during hyperoxia. Am. Rev. Respir. Dis. 125:231a. (Abstr.)

42. Freeman, B. A., and J. D. Crapo. 1982. Biology of disease: free radical injury to tissue. Lab. Invest. 47:412-426.

43. Majewska, M. D., J. Strosznajder, and J. Lazarewicz. 1978. Effect of ischemic anoxia and barbiturate anesthesia on free radical oxidation of mitochondrial phospholipids. Brain Res. 158:423-434. 